\title{
Hibiscus sabdariffa Linn fruit derivatives as alternative agents for diabetes mellitus care: A basic insight
}

\author{
Raheem Mohssin Shadhan ${ }^{\mathrm{a}}$, Zainah Adam ${ }^{\mathrm{b}}$, Siti Pauliena Mohd Bohari, ${ }^{\mathrm{a}, \mathrm{c}^{*}}$ \\ ${ }^{a}$ Department of Biosciences, Faculty of Sciences, Universiti Teknologi Malaysia, 81310 UTM, Johor Bahru, Johor, Malaysia \\ ${ }^{b}$ Medical Technology Division, Malaysian Nuclear Agency, Bangi, 43000 Kajang, Selangor, Malaysia \\ 'Institute of Bioproduct Development Universiti Teknologi Malaysia, 81310 UTM, Johor Bahru, Johor, Malaysia
}

Received 27th May 2021 / Accepted 13th September 2021

\begin{abstract}
This study discusses the effectiveness of methanolic extract and fractions (butanol, ethyl acetate, and n-hexane) of $H$. sabdariffa Linn fruit towards antidiabetic activities (in vitro). In order to test the efficacy, toxicity and insulin secretion capacity of rat pancreatic $\beta$-cell lines (BRIN-BD11) were tested with the methanolic extract and fractions. The outcomes showed that both the extract and the fractions demonstrated significantly lower levels of cytotoxic activities. Furthermore, the methanolic extract and fractions displayed varied sensitivity levels towards insulin release after an incubation period of $30 \mathrm{~min}$. The methanolic extract, at a concentration of $300 \mu \mathrm{g} / \mathrm{mL}$, significantly stimulated secretion of insulin by 2.85 -fold $(p<0.001)$. In addition, butanol, ethyl acetate, and $\mathrm{n}$-hexane fractions revealed a gradual increase in insulin secretion. The stimulated insulin secretion for these fractions had been recorded at 2 -fold $(p<0.01), 2.67$-fold, and 2.31-fold $(p<0.001)$, respectively, at the highest concentrations. The methanolic extract and fractions also appeared to stimulate secretion of insulin with all modulators present, for example, potassium chloride $(\mathrm{KCl})$, insulin secretion inhibitor (verapamil and diazoxide), as well as insulin secretagogue (tolbutamide and isobutylmethylxanthine (IBMX)). These results indicate that $H$. sabdariffa Linn fruit methanolic extract and fractions could indeed be beneficial for future development of antidiabetic drugs.
\end{abstract}

Keywords: Hibiscus sabdariffa Linn, fruit, in vitro study, diabetes, insulin, pancreatic $\beta$-cell

\section{INTRODUCTION}

A multitude of studies has revealed that the deterioration of insulin secretion and its ensuing effects can cause persistent hyperglycaemia amongst patients suffering from Type 2 diabetes mellitus (Ahmad and Ahmed, 2006; Guo and Tabrizchi, 2006). In fact, prolonged hyperglycaemia can lead to complications in diabetic pathogenesis (Ahmad and Ahmed, 2006; Fowler, 2008). Some of these complications are known to be associated with oxidative stress and low-grade chronic inflammation (Newsholme et al., 2016). Oxidative stress, an imbalance between cellular oxidant and antioxidant systems, results from the overproduction of free radicals and associated reactive oxygen species (ROS). HG upregulates the markers of chronic inflammation and contributes to increased ROS generation, which ultimately involves diabetes mellitus complications including vascular dysfunction (Luc et al., 2019). Other complications that include microvascular disease of the eye and kidney and a variety of clinical neuropathies (Clark Jr and Lee, 1995). At present, patients diagnosed with Type 2 diabetes mellitus are prescribed antidiabetic drugs as the treatment, such as meglitinides, thiazolidinedione, and sulphonylureas. Despite the accessibility of numerous antidiabetic agents, diabetes happens to remain a detrimental health

*Author for correspondence: Siti Pauliena Mohd Bohari, Department of Biosciences, Faculty of Sciences, Universiti Teknologi Malaysia, 81310 UTM, Johor Bahru, Johor, Malaysia. Email-pauliena@utm.my 
concern across the globe (Wild et al., 2004), primarily due to the adverse effects it has upon the human's health (Kirchheiner et al., 2005). For instance, treatment with sulphonylureas causes weight gain and hypoglycaemia (Chehade and Mooradian, 2000; Wei et al., 1998); meglitinides often sparks constant rhinitis, headache, bronchitis, and hypoglycaemia (Chehade and Mooradian, 2000); while thiazolidinedione results in fluid retention, weight gain, liver damage, and anaemia (Bell, 2002; Watkins and Whitcomb, 1998). Hence, dedicated efforts have been taken to develop alternative antidiabetic agents to overcome the shortcomings associated with the existing antidiabetic drugs prescribed as a treatment for patients diagnosed with Type 2 diabetes mellitus. Moreover, the literature has depicted that insulin secreted from pancreatic $\beta$ cells due to consumption of antidiabetic drugs may be advantageous in reducing hyperglycaemia (Bösenberg and van Zyl, 2008; Puri, 2001). The underlying mechanism that takes place through insulin secretion favours the uptake of glucose in the insulin-sensitive organs (e.g. liver and muscle), thereby diminishes hyperglycaemia (Patel and Mishra, 2008). On top of that, numerous medicinal herbs and their extracts have been introduced over the years for the treatment of diabetes (Patel and Zaveri, 2012).

The tropical plant H. sabdariffa Linn, which is also known as karkade or roselle, belongs to the family Malvaceae (Wang et al., 2000) and is extensively applied as a traditional medicine in treating hypertension, inflammation, as well as liver disorders (Wang et al., 2000). The aqueous extract of dried roselle flowers has been discovered to contain a high concentration of flavonoids that could be used for effective treatment of leukaemia and gastric carcinoma (Lin et al., 2007; Tseng et al., 2000). Besides, a study demonstrated (in vitro) that roselle leaves extract could possess some hypoglycaemic attributes (Sachdewa et al., 2001). Nevertheless, the hypoglycaemic properties of $H$. sabdariffa Linn fruit extracts have yet to be determined. As such, the potency of $H$. sabdariffa Linn fruit derived from methanolic extract and fractions (in vitro) were examined to determine and to suggest the feasibility of using them as alternative antidiabetic agents. With that, this study assessed the toxicity and insulin secretion ability of these derivatives by using rat pancreatic $\beta$-cell lines (BRIN BD11).

\section{MATERIALS AND METHODS}

\section{Chemical reagents}

D-glucose, Dimethyl sulfoxide (DMSO), and 3(4,5-Dimethylthiazol-2-yl)-2,5-

Diphenyltetrazolium Bromide (MTT) had been procured in analytical grade from Sigma-Aldrich Group (Selangor, Malaysia). Meanwhile, all supplements of cell culture had been obtained from Invitrogen (USA).

\section{Plant material and extraction procedure}

Some whole fruits of $H$. sabdariffa Linn were purchased from a local herbal shop (Johor Bahru, Malaysia). Running tab water. Then, the dried fruits were finely powdered using a grinder. The plant has been officially documented by the Forest Research Institute Malaysia (FRIM) with database card number 280615-14.

In order to obtain the first batch of crude extract, the powdered sample was soaked in methanol and water at a 4:1 ratio for $96 \mathrm{~h}$, following the specified procedure (Bohari et al., 2006). The extract, which turned gummy, was dried with a freeze dryer (Beta 2-4 LD plus LT, Martin Christ, Germany) after it was evaporated with a rotary evaporator (EYELA N-1000, EYELA, Tokyo, Japan). Following the same protocol, four batches of crude extracts were obtained and pooled (Bohari et al., 2006). The pooled extracts were finally subjected to a successive solvent-solvent partitioning from the least polar solvent (n-hexane) to the highest polarities (ethyl acetate and butanol). Next, the in vitro study of these methanolic extracts and fractions had been evaluated by using insulin secreted from pancreatic $\beta$ cells (Bohari et al., 2006).

\section{Cell culture}

The cell line that secretes insulin (BRIN BD11) had been retrieved from the European Collection of Cell Cultures (ECACC, Salisbury, UK). The obtained cell had been cultured at the Roswell Park Memorial Institute (RPMI) to prepare 1640 media, which was supplemented with $1 \%(\mathrm{v} / \mathrm{v})$ 
penicillin/streptomycin $\quad(10,000 \quad$ units/mL penicillin and $10 \mathrm{mg} / \mathrm{mL}$ streptomycin) and 10\% $(\mathrm{v} / \mathrm{v})$ foetal bovine serum (FBS) in an incubator that was humidified containing $95 \%$ air and $5 \%$ $\mathrm{CO}_{2}$ at $37^{\circ} \mathrm{C}$.

\section{Cell viability assay}

The assay that determined cell viability was prepared by adhering to the procedures prescribed by Fotakis et al. (2006). The cells at concentration $7 \times 10^{5}$ had been seed onto a plate with 96 wells, which was later incubated at $37^{\circ} \mathrm{C}$ for overnight. Then, it was treated with $H$. sabdariffa Linn fruit methanolic extract and fractions, as well as glibenclamide (positive control drug), for $72 \mathrm{~h}$. After incubation, $20 \mu \mathrm{L}$ of MTT ( $5 \mathrm{mg} / \mathrm{mL}$ ) had been added into every well and then, incubated again for $4 \mathrm{~h}$. Subsequently, the medium from each well had been gently aspirated, while $100 \mu \mathrm{L}$ of DMSO had been included in order to dissolve formazan crystals. After that, each plate was shaken for $5 \mathrm{~s}$, whereas the absorbance rate had been recorded at $570 \mathrm{~nm}$ with Anthos micro-plate reader (Beckman Coulter, USA).

\section{Insulin secretion assay}

Insulin secretion activity of $H$. sabdariffa Linn fruit methanolic extract and fractions had been assessed with cells of BRIN-BD11. Besides, the fundamental features and the production of insulin-secreting cell lines have been recorded in this study (McClenaghan et al., 1996). The insulin secretion assay was conducted by using a slightly modified method, where the cells at a concentration of $1 \times 10^{6}$ were seeded in a plate with 96 wells, which was incubated overnight at $37^{\circ} \mathrm{C}$ before attachment was carried out. Next, the cells had been washed thrice on the next day by using Krebs-Ringer Bicarbonate Buffer (KRB), which was later incubated again for $40 \mathrm{~min}$ at $37^{\circ} \mathrm{C}$. After that, the cells went through incubation for additional $30 \mathrm{~min}$ after adding 1 $\mathrm{mL}$ of $\mathrm{KRB}$ (negative control) or $1 \mathrm{~mL}$ of $\mathrm{KRB}$ containing gradient concentrations of $H$. sabdariffa Linn fruit methanolic extract and fractions or 1 $\mathrm{mL}$ of KRB containing glibenclamide (positive control). All evaluations were carried out with glucose $(2 \mathrm{mM})$. After the incubation process, 1 $\mathrm{mL}$ of aliquots taken from every well had been placed into $1.5 \mathrm{~mL}$ tubes and later kept at $-20^{\circ} \mathrm{C}$ in order to determine concentration of insulin (Gray et al., 2000).

\section{Determination of insulin secretion mechanisms of $300 \mu \mathrm{g} / \mathrm{mL}$ methanolic extract}

The methanolic extract of $300 \mu \mathrm{g} / \mathrm{mL}$ had been applied in order to identify mechanisms involved in insulin secretion. The methanolic extract concentration had been selected based on the results obtained in insulin secretion assay. In order to assess the related mechanism, the extract was incubated along with some modulators that have been reckoned to influence the channel of secondary messenger found in pancreatic $\beta$-cells. These modulators, including potassium chloride $(\mathrm{KCl})$, insulin secretion inhibitor (verapamil and diazoxide), as well as insulin secretagogue (tolbutamide and isobutyl methylxanthine (IBMX)), set at a depolarizing concentration, had been used. Next, the cells of BRIN-BD11 $\left(1 \times 10^{6}\right.$ cells/well) had been seeded in a plate with 96 wells and had been left at $37^{\circ} \mathrm{C}$ at overnight, $\mathrm{CO}_{2}(5 \%)$ for attachment purpose before acute assessment. After being incubated for an overnight, the cells were washed three times using $\mathrm{KRB}$, and later incubated again with $\mathrm{KRB}$ at $37^{\circ} \mathrm{C}$ for $40 \mathrm{~min}$. Next, the cells went through incubation for an additional of $30 \mathrm{~min}$ after including $1 \mathrm{~mL}$ of $\mathrm{KRB}$ that consisted of methanolic extract $(300 \mu \mathrm{g} / \mathrm{mL})$ in both the presence and the absence of tolbutamide, IBMX, verapamil, $\mathrm{KCl}$, and diazoxide at concentrations of $200 \mu \mathrm{M}, 100 \mu \mathrm{M}$, $30 \mathrm{mM}, 50 \mathrm{mM}$, and $300 \mu \mathrm{M}$. All the tests were performed in the presence of glucose $(2 \mathrm{mM})$. Following the incubation, $1 \mathrm{~mL}$ of aliquots from each well was placed at $-20^{\circ} \mathrm{C}$ in $1.5 \mathrm{~mL}$ tubes for insulin assay.

\section{Statistical analysis}

Each measurement was carried out thrice to calculate the average and the standard deviation (SD) values. Besides, SPSS 21 software package (Windows Evaluation Version, SPSS Inc., USA) had been employed to perform statistical analysis upon the empirical data retrieved. After that, the Shapiro-Wilk assessment had been carried out in order to ensure data normality. Furthermore, independent $t$-test and Mann-Whitney test were performed to analyses normal and abnormal data, respectively. If the value of probability ( $p$ ) 
determined is below 0.05 , the data are considered as significant (Pallant, 2007).

\section{RESULTS}

\section{Cell viability assay}

Table 1 portrays the effects of $H$. sabdariffa Linn fruit (methanolic extract and fractions) and glibenclamide upon the viability of BRIN BD11 cell. The $\mathrm{IC}_{50}$ value for the methanolic extract and fractions were calculated to determine their cytotoxic effect on the insulin secretion activity. As a result, it was found that n-hexane and butanol fractions displayed high cytotoxic effect upon BRIN BD11 cells with $\mathrm{IC}_{50}$ values of 316 $\mu \mathrm{g} / \mathrm{mL}$ and $181 \mu \mathrm{g} / \mathrm{mL}$, respectively. Nevertheless, the methanolic extract and the ethyl acetate exhibited lower toxicity effect upon BRIN BD11 cells with $\mathrm{IC}_{50}$ values of $346 \mu \mathrm{g} / \mathrm{mL}$ and $363 \mu \mathrm{g} / \mathrm{mL}$, respectively. Next, glibenclamide was used as a standard reference to challenge the insulin secreting activity of $H$. sabdariffa Linn fruit methanolic extract and fractions against BRIN $\mathrm{BD} 11$ cells. The $\mathrm{IC}_{50}$ value for glibenclamide was noted to be at $489 \mu \mathrm{g} / \mathrm{mL}$, which signified that glibenclamide exerted lower cytotoxic effect upon BRIN BD11 cells, in comparison to that of the extract and fractions of roselle.

\section{Insulin secretion}

Figure 1 displays the impact of methanolic extract and fractions of $H$. sabdariffa Linn fruit, as well as glibenclamide, upon insulin secretion ability from BRIN BD11 cells. Meanwhile, in comparison to the negative control, methanolic extract at 300 $\mu \mathrm{g} / \mathrm{mL}$ exhibited higher insulin secretion activity (2.85-fold, $p<0.001)$. On the other hand, the ethyl acetate fraction at concentration $350 \mu \mathrm{g} / \mathrm{mL}$ showed a step-wise stimulating effect on the secretion of insulin, when compared to the negative control, with the highest stimulation at 2.67-fold. Additionally, the n-hexane and butanol fractions illustrated high potential dosedependent stimulatory effect at $2.31-(p<0.001)$ and 2-fold $(p<0.01)$ for $300 \mu \mathrm{g} / \mathrm{mL}$ and 150 $\mu \mathrm{g} / \mathrm{mL} \quad$ concentrations, respectively. Nevertheless, all the roselle derivatives showed inhibition for insulin secretion at concentrations above $\mathrm{IC}_{50}$. On the other hand, glibenclamide appeared to have significantly stimulated insulin secretion by 3.23 -fold $(p<0.001)$ at the highest concentration of $0.2 \mathrm{mM}$. From the outcomes retrieved, methanolic extract seems to be a better insulin secretion stimulator, in comparison to other fractions, although its efficacy appears lower than glibenclamide (positive control).

\section{Insulin secretion mechanisms of $300 \mu \mathrm{g} / \mathrm{mL}$ methanolic extract}

The impact displayed by modulators for insulin secretion upon $H$. sabdariffa methanolic extract treatment $(300 \mu \mathrm{g} / \mathrm{mL})$ towards BRIN BD11 cells insulin secretion had been assessed with basal glucose $(2 \mathrm{mM})$ (Figure 2$)$. The specific concentration of methanolic extract $(300 \mu \mathrm{g} / \mathrm{mL})$ produced a significant insulin secretion activity, as stated above. Likewise, the extract also stimulated significant insulin secretion with all modulators present, but except for verapamil $(50 \mathrm{mM})$. The magnitudes of stimulation were $2-(p<0.001)$, 2.96- $(p<0.001), 5.77-(p<0.001)$, and 7.48-fold $(p<0.001)$ when tested with diazoxide $(300 \mu \mathrm{M})$, IBMX $(100 \mu \mathrm{M})$, tolbutamide $(200 \mu \mathrm{M})$, as well as $\mathrm{KCl}(30 \mathrm{mM})$, respectively, in comparison to the corresponding incubation without methanolic extract $(300 \mu \mathrm{g} / \mathrm{mL})$. Furthermore, with $\mathrm{KCl}$ and tolbutamide present, the insulin secretion activity of methanolic extract $(300 \mu \mathrm{g} / \mathrm{mL})$ escalated by a factor of 1.96- $(p<0.001)$ and 1.56-fold $(p<0.001)$, accordingly. On the contrary, with the presence of diazoxide and verapamil have strongly inhibited the activity of insulin release for methanolic extract $(300 \mu \mathrm{g} / \mathrm{mL})$ by $0.49-(p<0.001$, as well as 0.79 -fold, accordingly. In addition, the IBMX had minimal to nil effect upon insulin release for the extract. 
Table 1. Cell viability of BRIN BD11 cells against varying concentrations of $H$. sabdariffa Linn fruit (methanolic extract and fractions) and glibenclamide. Mean \pm SD values for three replicates, in comparison to control, are as follows: ${ }^{*} p<0.05, * * p<0.01$, and ${ }^{* * *} p<0.001$.

\begin{tabular}{|c|c|c|c|c|c|c|c|c|c|c|}
\hline $\begin{array}{l}\text { Concentration } \\
(\mu \mathrm{g} / \mathrm{mL})\end{array}$ & Control & 7.81 & 15.63 & 31.25 & 62.5 & 125 & 250 & 500 & 1000 & $\begin{array}{c}\mathrm{IC}_{50} \\
(\mu \mathrm{g} / \mathrm{mL})\end{array}$ \\
\hline \multirow{3}{*}{ Methanol } & \multirow{3}{*}{$\begin{aligned} & 100 \\
\pm & 0.006\end{aligned}$} & $* * *$ & $*$ & $* * *$ & & $*$ & $* * *$ & ** & $*$ & \multirow{3}{*}{320} \\
\hline & & 92.14 & 85.06 & 79.66 & 76.91 & 65.77 & 53.99 & 37.1 & 16.91 & \\
\hline & & \pm 0.003 & \pm 0.009 & \pm 0.007 & \pm 0.004 & \pm 0.006 & \pm 0.019 & \pm 0.218 & \pm 0.022 & \\
\hline \multirow{3}{*}{ n-hexane } & \multirow{3}{*}{$\begin{array}{c}100 \\
\pm 0.020\end{array}$} & $* *$ & $* *$ & $*$ & ** & $*$ & $* * *$ & $* *$ & ** & \multirow{3}{*}{316} \\
\hline & & 94.29 & 91.17 & 84.5 & 76.08 & 68.22 & 55.52 & 38.08 & 26.64 & \\
\hline & & \pm 0.007 & \pm 0.022 & \pm 0.037 & \pm 0.068 & \pm 0.011 & \pm 0.013 & \pm 0.003 & \pm 0.005 & \\
\hline \multirow{3}{*}{ Ethyl acetate } & \multirow{3}{*}{$\begin{aligned} & 100 \\
\pm & 0.017\end{aligned}$} & $*$ & $* *$ & $* *$ & ** & $*$ & $* * *$ & $* * *$ & $* *$ & \multirow{3}{*}{369} \\
\hline & & 96.43 & 91.43 & 84.12 & 80.33 & 75.16 & 59.52 & 42.82 & 18.06 & \\
\hline & & \pm 0.012 & \pm 0.002 & \pm 0.004 & \pm 0.006 & \pm 0.012 & \pm 0.007 & \pm 0.021 & \pm 0.022 & \\
\hline \multirow{3}{*}{ Butanol } & \multirow{3}{*}{$\begin{aligned} & 100 \\
\pm & 0.017\end{aligned}$} & * & $* *$ & $*$ & $* * *$ & $*$ & $* * *$ & $* *$ & $* * *$ & \multirow{3}{*}{181} \\
\hline & & 94.5 & 92.74 & 91.25 & 81.32 & 63.99 & 39.9 & 30.69 & 13.8 & \\
\hline & & \pm 0.012 & \pm 0.002 & \pm 0.004 & \pm 0.006 & \pm 0.012 & \pm 0.007 & \pm 0.021 & \pm 0.022 & \\
\hline \multirow{3}{*}{ Glibenclamide } & \multirow{3}{*}{$\begin{aligned} & 100 \\
\pm & 0.013\end{aligned}$} & $* * *$ & $*$ & & $*$ & $*$ & $* * *$ & $* *$ & $* *$ & \multirow{3}{*}{464} \\
\hline & & 98.43 & 97.12 & 92.63 & 83.81 & 75.38 & 57.83 & 49.23 & 27.43 & \\
\hline & & \pm 0.017 & \pm 0.027 & \pm 0.017 & \pm 0.052 & \pm 0.047 & \pm 0.016 & \pm 0.034 & \pm 0.024 & \\
\hline
\end{tabular}



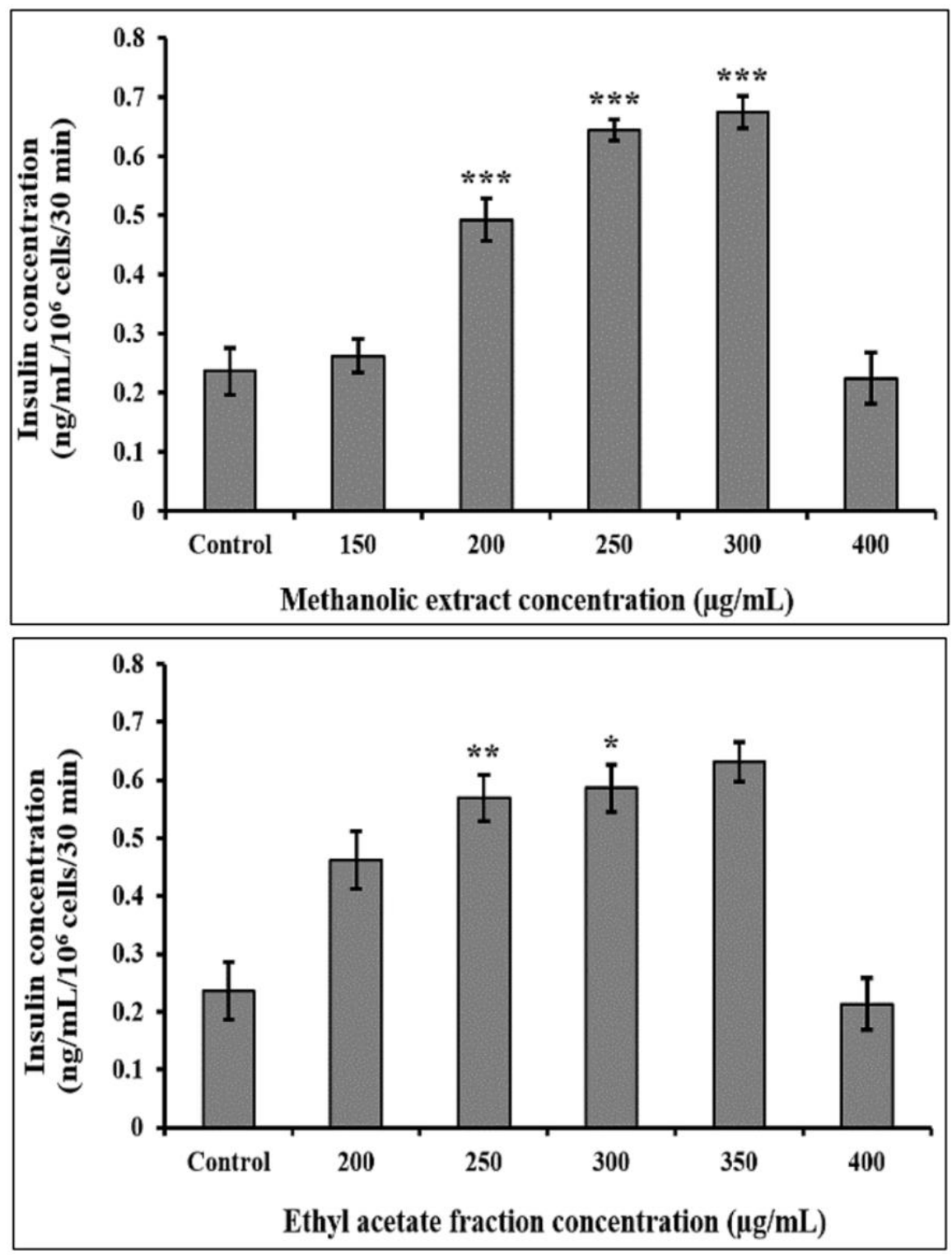

Figure 1. Insulin secretion activity of BRIN BD11 cells against $H$. sabdariffa Linn fruit (methanolic extract and fractions), as well as glibenclamide. The values refer to mean \pm SD based on four replicates with $* * * p<0.001$, in comparison to that of control. 

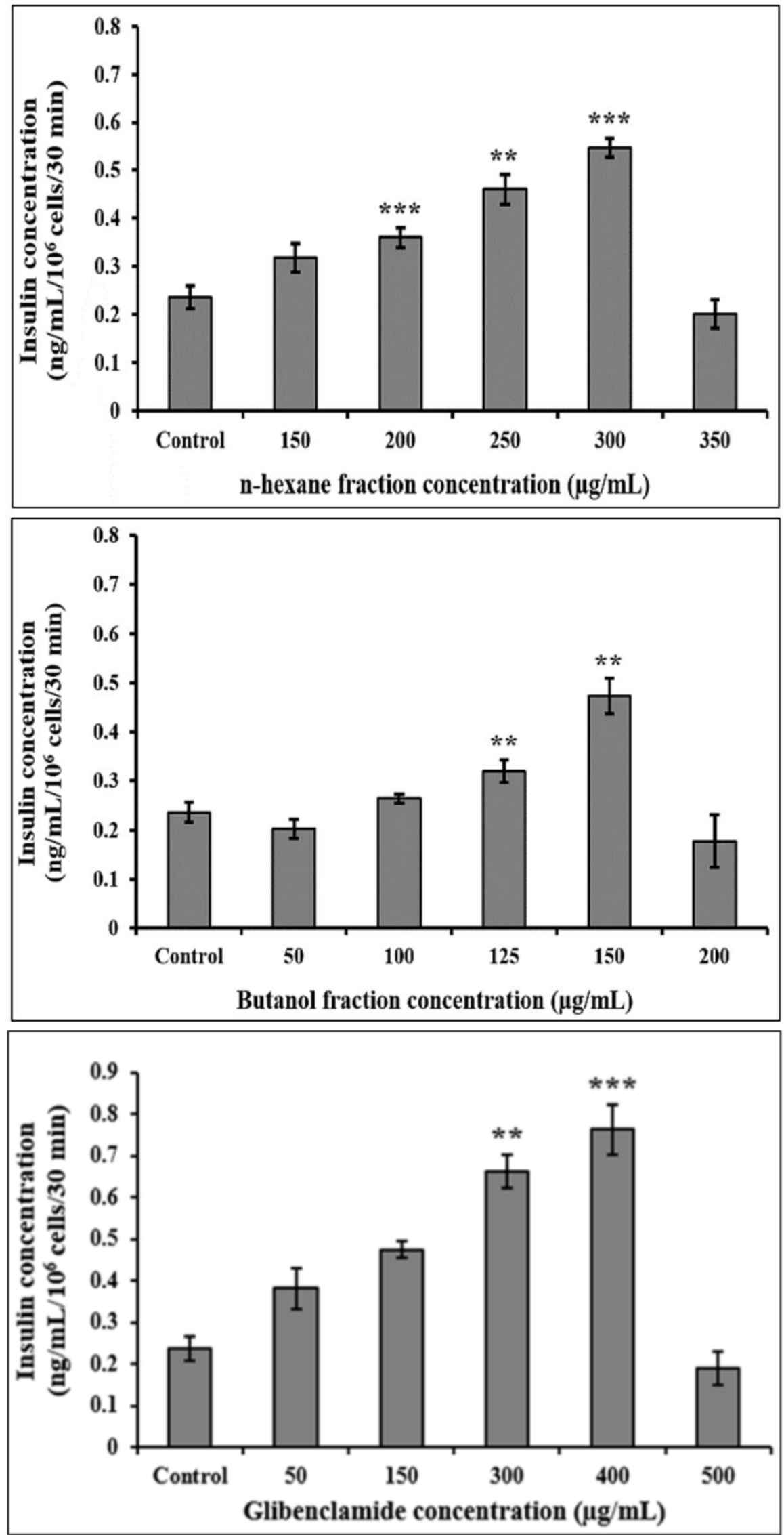

Figure 1 (continued). Insulin secretion activity of BRIN BD11 cells against H. sabdariffa Linn fruit (methanolic extract and fractions), as well as glibenclamide. The values refer to mean $\pm \mathrm{SD}$ based on four replicates with $* * * p<0.001$, in comparison to that of control. 


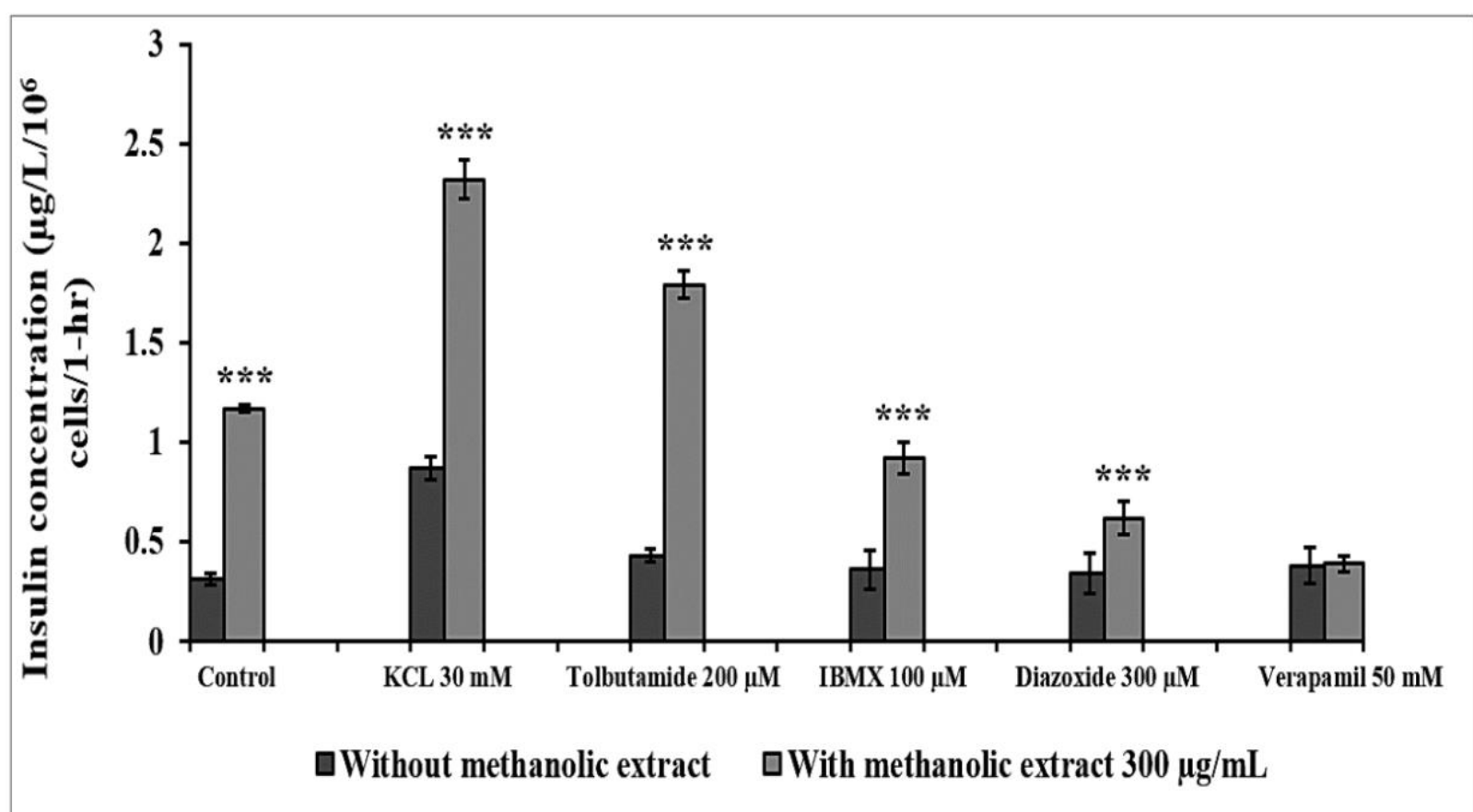

Figure 2. The effect exhibited by modulators of insulin secretion upon $300 \mu \mathrm{g} / \mathrm{mL}$ of methanolic extract towards BRIN BD11 cells insulin secretion. The values denote mean \pm SD from four replicates ${ }^{* * *} p<0.001$, in comparison to incubations without $300 \mu \mathrm{g} / \mathrm{mL}$ of methanolic extract.

\section{DISCUSSION}

This research work reveals the influence of methanolic extract, as well as its fractions, from H. sabdariffa Linn fruit on insulin secretion capacity by using BRIN-BD11 cell lines. The outcomes strongly postulate that methanolic extract and fractions derived from $H$. sabdariffa Linn fruit can be applied as an effective antidiabetic agent, in comparison to several other reported compounds. For instance, nutrient regulation can positively induce insulin secretion in BRIN BD11 cell lines (Gray et al., 2000). Also, treatments using nymphayol (Gembal et al., 1992), C. colocynthis (Evans and Rushakoff, 2002), and Achillea millefolium L. (Asteraceae) (Kecskemeti et al., 2002) revealed that secretion of insulin was enhanced due to glucose stimulation via in vitro by 2.1- $(p<0.05), 1.8$-, and 2.3-fold ( $p<0.001$ ), when compared to the control group respectively. Furthermore, the addition of a dose of Hank's balanced salt solution $(0.1 \mathrm{mg} / \mathrm{mL})$ can also efficiently induce secretion of insulin. Besides, three new flavonoids isolated from Pseudarthria hookeri also demonstrated a mild effect on the secretion of insulin when stimulated with glucose (Tchamgoue et al., 2016). Nevertheless, the increase noted for insulin secretion in the aforementioned compounds is not as effective as that portrayed by methanolic extract from roselle.

In order to determine the insulin secretion mechanism, the methanolic extract $(300 \mu \mathrm{g} / \mathrm{mL})$ had been incubated in both presence and absence of modulators for the secretion of insulin. For instance, depolarization of $\mathrm{KCl}(30 \mathrm{mM})$, the insulinotropic antagonist (verapamil and diazoxide), as well as an insulinotropic agonist (IBMX and tolbutamide). The results showed that tolbutamide, which derives from the Sulphonylureas group has been reckoned to be a hypoglycaemic agent, displayed the potential to stimulate the release of insulin via channeldependent $\mathrm{K}_{\text {ATP }}^{+}$pathway (Chehade and Mooradian, 2000; Evans and Rushakoff, 2002; Gembal et al., 1992). This is because tolbutamide closes the path of $\mathrm{K}_{\text {ATP, }}^{+}$apart from stimulating the $\mathrm{Ca}^{2+}$ influx by activating voltage-dependent $\mathrm{Ca}^{2+}$ channel (VDCC), as well as by depolarizing plasma membrane (Kecskemeti et al., 2002). As for this research work, the tolbutamide augmented the effect of secreting insulin in 
methanolic extract $(300 \mu \mathrm{g} / \mathrm{mL})$, thus signifying the involvement of $\mathrm{K}_{\text {ATP }}^{+}$that depends on channel (Hannan et al., 2007).

On top of that, it has been reported that IBMX, which is a phosphodiesterase inhibitor, can enhance the release of insulin by escalating the levels of intracellular cAMP in pancreatic $\beta$-cells (Siegel et al., 1980). Nevertheless, this study found that IBMX failed in inducing insulin secretion for methanolic extract $(300 \mu \mathrm{g} / \mathrm{mL})$, thus dismissing the involvement of cAMP in the process (Hannan et al., 2007). The diazoxide, which has been known to open channels of $\mathrm{K}^{+}{ }_{\mathrm{ATP}}$, has been reported to inhibit insulin secretion by activating the channels of $\mathrm{K}_{\text {ATP }}^{+}$in $\beta$-cells (Gembal et al., 1992; Gray et al., 2000). As for this research, the diazoxide inhibited the effects of insulin secretion for methanolic extract $(300 \mu \mathrm{g} / \mathrm{mL})$, which points out that the release of insulin is attributable to the activated channel of $\mathrm{K}^{+}{ }_{\text {ATP. Nonetheless, it was found that }}$ the diazoxide could only inhibit, but not halt the effect of methanolic extract $(300 \mu \mathrm{g} / \mathrm{mL})$ on insulin secretion, as illustrated in Figure 2. This finding suggests that the insulin-release inducing effect of methanolic extract $(300 \mu \mathrm{g} / \mathrm{mL})$ could have embedded the pathway of channeldependent $\mathrm{K}_{\text {ATP }}^{+}$(Mathews et al., 2006). This notion is supported by the observation of $\mathrm{KCl}$ (30 $\mathrm{mM}$ ) that ultimately had the cell membranes depolarized. The augmented insulin secretion displayed by methanolic extract $(300 \mu \mathrm{g} / \mathrm{mL})$ in a depolarized state signifies the involvement of $\mathrm{K}^{+}{ }_{\text {ATP }}$ channel-independent pathway (Gray et al., 2000; McClenaghan, 2007), but this does not portray the mechanism of the molecular underpinning the pathway. The trigger of insulin secretion is possible due to shifts in adenine nucleotide concentration (Sato and Henquin, 1998) or due to the stimulating effect of $\mathrm{Ca}^{2+}$ on the insulin-releasing process (Gembal et al., 1992), which occur at the pathway of channelindependent $\mathrm{K}^{+}{ }_{\text {ATP. }}$.

Lastly, the verapamil, which derives from phenylalkylamines class, has been reckoned to be a VDCC blocker of the L-type that inhibits the secretion of insulin by hindering influx of $\mathrm{Ca}^{2+}$ in cells (Lebrun et al., 1997) as for this research, it was discovered that verapamil strongly inhibited, but not to the extent of totally halting the effects of methanolic extract $(300 \mu \mathrm{g} / \mathrm{mL})$ on the secretion of insulin in BRIN-BD11 cells. This appears to be an indication that the effect of the extract tested upon release of insulin had been dependent on extracellular $\mathrm{Ca}^{2+}$ through activated VDCC. However, secretion of insulin may also take place without the presence of extracellular $\mathrm{Ca}^{2+}$ as the release of insulin can be enhanced by the extract due to stored intracellular $\mathrm{Ca}^{2+}$ mobilization (Hannan et al., 2007). Additionally, another viable method to promote the release of insulin by the extract with verapamil present refers to $\mathrm{Ca}^{2+}$ influx, which may take place via other $\mathrm{Ca}^{2+}$ channels, for instance, voltageoperated $\mathrm{Ca}^{2+}$ channel (VOCC) and $\mathrm{N}$-type $\mathrm{Ca}^{2+}$ channel, thus increasing the $\mathrm{Ca}^{2+}$ intracellular concentration (Liu et al., 2003; Satin et al., 1995; Vajna et al., 2001).

This study demonstrated that methanolic extract $(300 \mu \mathrm{g} / \mathrm{mL})$ from $H$. sabdariffa Linn fruit possesses superior insulin secretion activity by a factor of 2.85-fold ( $p<0.001)$, in comparison to the negative control (cells without treatment). Hence, the present observations suggest that the methanolic extract from $H$. sabdariffa Linn fruit is a suitable candidate for the development of a new oral antidiabetic drug to stimulate secretion of insulin.

\section{CONCLUSION}

This study demonstrated that the methanolic extract and fractions from $H$. sabdariffa Linn fruit at controlled concentrations successfully stimulate secretion of insulin in BRIN BD11 cells. The findings showed that the property of antihyperglycaemic in H. sabdariffa Linn fruit had been mediated by stimulation of insulin secretion from the pancreatic $\beta$-cells. In short, the systematic experimentation, as well as the in-depth analyses undertaken in this research, reveals the prospect for progression of oral hypoglycaemic drug by using methanolic extract and fractions of $H$. sabdariffa Linn fruit.

\section{ACKNOWLEDGEMENTS}

The authors wish to express their gratitude to the Ministry of Higher Education and Scientific 
Research of Iraq for the financial assistance, laboratory facilities of Tissue Engineering Laboratory FS, IBD, at Universiti Teknologi Malaysia.

\section{CONFLICT OF INTEREST}

The authors have declared that no conflict of interest exists.

\section{REFERENCES}

Ahmad, M. S. \& Ahmed, N. 2006. Antiglycation properties of aged garlic extract: possible role in prevention of diabetic complications. The Journal of Nutrition 136(3): 796S-799S.

Bell, D. S. 2002. current status of diabetes treatment. (Featured CME Topic: Diabetes Mellitus). Southern Medical Journal 95(1): 24-30.

Bohari, M., Pauliena, S., Hamid, M., Shaari, K., \& Lajis, N. 2006. Glucose uptake: Stimulatory activity of Gynura procumbens in 3T3-F442A adipocytes.

Bösenberg, L. H. \& van Zyl, D. G. 2008. The mechanism of action of oral antidiabetic drugs: a review of recent literature. Journal of Endocrinology, Metabolism and Diabetes of South Africa 13(3): 80-88.

Chehade, J. M. \& Mooradian, A. D. 2000. A rational approach to drug therapy of type 2 diabetes mellitus. Drugs 60(1): 95113.

Clark Jr, C. M. \& Lee, D. A. 1995. Prevention and treatment of the complications of diabetes mellitus. New England Journal of Medicine 332(18): 1210-1217.

Evans, J. \& Rushakoff, R. 2002. Oral pharmacological agents for type 2 diabetes: sulfonylureas, meglitinides, metformin, thiazolidinediones, $\alpha$-glucosidase inhibitors, and emerging approaches. Diabetes and Carbohydrate Metabolism.

Fotakis, G. \& Timbrell, J. A. 2006. In vitro cytotoxicity assays: comparison of LDH, neutral red, MTT and protein assay in hepatoma cell lines following exposure to cadmium chloride. Toxicology Letters 160(2): 171-177.

Fowler, M. J. 2008. Microvascular and macrovascular complications of diabetes. Clinical Diabetes 26(2): 77-82.

Gembal, M., Gilon, P., \& Henquin, J.-C. 1992. Evidence that glucose can control insulin release independently from its action on ATP-sensitive $\mathrm{K}+$ channels in mouse B cells. Journal of Clinical Investigation 89(4): 1288.

Gray, A., Abdel-Wahab, Y., \& Flatt, P. 2000. Insulin-like and insulin-releasing actions of the traditional antidiabetic plant Sambucus nigra (elder). Journal of Nutrition 130(1): 15-20.

Guo, L. \& Tabrizchi, R. 2006. Peroxisome proliferator-activated receptor gamma as a drug target in the pathogenesis of insulin resistance. Pharmacology \& Therapeutics 111(1): 145173.

Hannan, J., Marenah, L., Ali, L., Rokeya, B., Flatt, P. R., \& AbdelWahab, Y. H. 2007. Insulin secretory actions of extracts of Asparagus racemosus root in perfused pancreas, isolated islets and clonal pancreatic $\beta$-cells. Journal of Endocrinology, 192(1): 159-168.
Kecskemeti, V., Bagi, Z., Pacher, P., Posa, I., Kocsis, E., \& Koltai, M. 2002. New trends in the development of oral antidiabetic drugs. Current Medicinal Chemistry 9(1): 53-71.

Kirchheiner, J., Roots, I., Goldammer, M., Rosenkranz, B., \& Brockmöller, J. 2005. Effect of genetic polymorphisms in cytochrome P450 (CYP) 2C9 and CYP2C8 on the pharmacokinetics of oral antidiabetic drugs. Clinical Pharmacokinetics 44(12): 1209-1225.

Lebrun, P., Antoine, M.-H., Ouedraogo, R., Pirotte, B., Herchuelz, A., Cosgrove, K. E., et al. 1997. Verapamil, a phenylalkylamine $\mathrm{Ca}^{2+}$ channel blocker, inhibits ATPsensitive $\mathrm{K}^{+}$channels in insulin-secreting cells from rats. Diabetologia 40(12): 1403-1410.

Lin, T.-L., Lin, H.-H., Chen, C.-C., Lin, M.-C., Chou, M.-C., \& Wang, C.-J. 2007. Hibiscus sabdariffa extract reduces serum cholesterol in men and women. Nutrition Research 27(3): 140145.

Liu, Y.-J., Cheng, H., Drought, H., MacDonald, M. J., Sharp, G. W., \& Straub, S. G. 2003. Activation of the $\mathrm{K}_{\text {ATP }}$ channelindependent signaling pathway by the nonhydrolyzable analog of leucine, BCH. American Journal of PhysiologyEndocrinology and Metabolism 285(2): E380-E389.

Luc, K., Schramm-Luc, A., Guzik, T., \& Mikolajczyk, T. 2019. Oxidative stress and inflammatory markers in prediabetes and diabetes. Journal of Physiology and Pharmacology 70(6): 809824.

Mathews, J. N., Flatt, P. R., \& Abdel-Wahab, Y. H. 2006. Asparagus adscendens (Shweta musali) stimulates insulin secretion, insulin action and inhibits starch digestion. British Journal of Nutrition 95(3): 576-581.

McClenaghan, N., Barnett, C., O'Harte, F., \& Flatt, P. 1996. Mechanisms of amino acid-induced insulin secretion from the glucose-responsive BRIN-BD11 pancreatic B-cell line. Journal of Endocrinology 151(3): 349-357.

McClenaghan, N. H. 2007. Physiological regulation of the pancreatic $\beta$-cell: functional insights for understanding and therapy of diabetes. Experimental Physiology 92(3): 481-496.

Newsholme, P., Cruzat, V. F., Keane, K. N., Carlessi, R., \& de Bittencourt Jr, P. I. H. 2016. Molecular mechanisms of ROS production and oxidative stress in diabetes. Biochemical Journal 473(24): 4527-4550.

Pallant, J. 2007. SPSS survival manual: A step-by-step guide to data analysis using SPSS version 15. Maidenhead, Berkshire, England: MoGraw-Hill Education.

Patel, M. \& Mishra, S. 2008. PHCOG REV.: Invited review cell lines in diabetes research: A review. Pharmacognosy Reviews 2(4): 188-205.

Patel, S. S. \& Zaveri, M. N. 2012. Cytotoxic activity to find bioactive compound from Justicia gendarussa using brine shrimp lethality assay. Asian Journal of Traditional Medicines, 7(3): 102-108.

Puri, D. 2001. The insulinotropic activity of a Nepalese medicinal plant Biophytum sensitivum: Preliminary experimental study. Journal of Ethnopharmacology 78(1): 89-93.

Sachdewa, A., Nigam, R., \& Khemani, L. 2001. Hypoglycemic effect of Hibiscus rosa sinensis L. leaf extract in glucose and streptozotocin induced hyperglycemic rats. Indian Journal of Experimental Biology 39(3): 284-286.

Satin, L., Tavalin, S., Kinard, T., \& Teague, J. 1995. Contribution of L-and non-L-type calcium channels to voltage-gated calcium current and glucose-dependent insulin secretion in HIT-T15 cells. Endocrinology 136(10): 4589-4601.

Sato, Y. \& Henquin, J.-C. 1998. The $\mathrm{K}^{+}$-ATP channel-independent pathway of regulation of insulin secretion by glucose. Diabetes 47: 1713-1721.

Siegel, E., Wollheim, C., Kikuchi, M., Renold, A., \& Sharp, G. 1980. Dependency of cyclic AMP-induced insulin release 
on intra-and extracellular calcium in rat islets of Langerhans. Journal of Clinical Investigation 65(2): 233.

Tchamgoue, J., Hafizur, R. M., Tchouankeu, J. C., Kouam, S. F., Adhikari, A., Hameed, A., et al. 2016. Flavonoids and other constituents with insulin secretion activity from Pseudarthria bookeri. Phytochemistry Letters 17: 181-186.

Tseng, T.-H., Kao, T.-W., Chu, C.-Y., Chou, F.-P., Lin, W.-L., \& Wang, C.-J. 2000. Induction of apoptosis by hibiscus protocatechuic acid in human leukemia cells via reduction of retinoblastoma (RB) phosphorylation and $\mathrm{Bcl}-2$ expression. Biochemical Pharmacology 60(3): 307-315.

Vajna, R., Klöckner, U., Pereverzev, A., Weiergräber, M., Chen, X. h., Miljanich, G., et al. 2001. Functional coupling between 'R-type' $\mathrm{Ca}^{2+}$ channels and insulin secretion in the insulinoma cell line INS-1. The FEBS Journal 268(4): 10661075.

Wang, C.-J., Wang, J.-M., Lin, W.-L., Chu, C.-Y., Chou, F.-P., \& Tseng, T.-H. 2000. Protective effect of Hibiscus anthocyanins against tert-butyl hydroperoxide-induced hepatic toxicity in rats. Food and Chemical Toxicology 38(5): 411-416.

Watkins, P. B. \& Whitcomb, R. W. 1998. Hepatic dysfunction associated with troglitazone. New England Journal of Medicine 338(13): 916-917.

Wei, M., Gaskill, S. P., Haffner, S. M., \& Stern, M. P. 1998. Effects of diabetes and level of glycemia on all-cause and cardiovascular mortality: the San Antonio Heart Study. Diabetes Care 21(7): 1167-1172.

Wild, S., Roglic, G., Green, A., Sicree, R., \& King, H. 2004. Global prevalence of diabetes estimates for the year 2000 and projections for 2030. Diabetes Care 27(5): 1047-1053. 